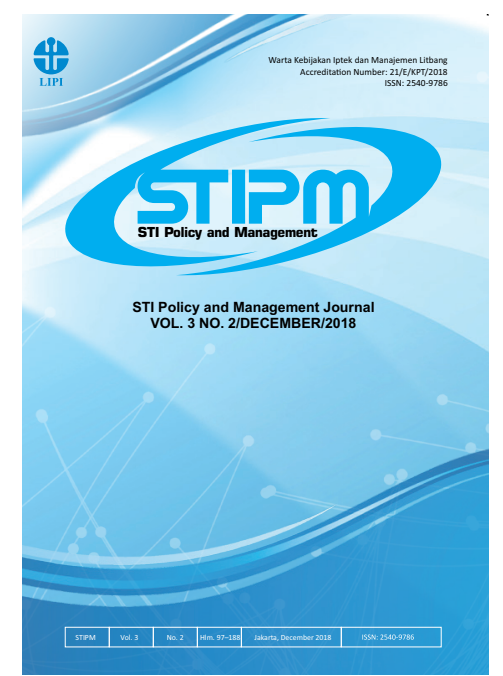

Journal of STI Policy and Management

Publication details, including instructions for authors and subscription information: http://www.stipmjournal.org/

\title{
National Innovation Capability Variables and Dimensions
}

Ahmad Dading Gunadi ${ }^{1}$, Yandra Arkeman², Rizal Syarief Siaiful Nazli $^{3}$, Teguh Rahardjo ${ }^{4}$, Aulijati Wachjudiningsih ${ }^{5}$

${ }^{1}$ Ministry of National Development Planning, Jakarta

${ }^{2}$ Bogor Agricultural University, Bogor

${ }^{3}$ Bogor Agricultural University, Bogor

${ }^{4}$ DIPI, Jakarta

${ }^{5}$ PT Geodipa Energi

Version of record first published: 15 December 2018

To cite this article: Gunadi, A.D., Arkerman, Y., Nazli, R.S.S., Rahardjo, T., and Wachjudiningsih, A. (2018). National Innovation Capability Variables and Dimensions. Journal of STI Policy and Management, 3(2), 175-188 To link to this article: http://dx.doi.org/10.14203/STIPM.2017.138

ISSN 2540-9786 (Print); ISSN 2502-5996 (online)

Accreditation Number: 21/E/KPT/2018

Full terms and conditions of use: https://creativecommons.org/licenses/by-nc-sa/4.0/

You are free to:

- Share : copy and redistribute the material in any medium or format

- Adapt : remix, transform, and build upon the material

- The licensor cannot revoke these freedoms as long as you follow the license terms.

Under the following terms: Attribution - You must give appropriate credit, provide a link to the license, and indicate if changes were made. You may do so in any reasonable manner, but not in any way that suggests the licensor endorses you or your use.

$\$$ NonCommercial - You may not use the material for commercial purposes.

(3) ShareAlike - If you remix, transform, or build upon the material, you must distribute your contributions under the same license as the original.

No additional restrictions - You may not apply legal terms or technological measures that legally restrict others from doing anything the license permits.

Notices:

- You do not have to comply with the license for elements of the material in the public domain or where your use is permitted by an applicable exception or limitation.

- No warranties are given. The license may not give you all of the permissions necessary for your intended use. For example, other rights such as publicity, privacy, or moral rights may limit how you use the material.

- If you copy the dataset merely to extract the uncopyrightable data elements would not need permission to do so. However, if you republish the full dataset or using the copyrightable data layers require a permission from PAPPIPTEK-LIPI. 


\title{
JOURNAL OF SCIENCE, TECHNOLOGY, AND INNOVATION POLICY AND MANAGEMENT (STIPM JOURNAL), Volume 03, Number 02, December 2018
}

\author{
FOREWORD by EDITOR-in-CHIEF
}

We are very pleased to inform the readers that Journal of Science, Technology, \& Innovation Policy and Management (STIPM Journal) Vol. 3, No. 2, December 2018 is now ready for public reading and views. STIPM Journal is an online research journal, managed by the Center for Science and Technology Development Studies, Indonesian Institute of Sciences (PAPPIPTEK-LIPI).

This journal in fact provides scientific information needed mostly by research scholars. As a peer reviewed journal, STIPM provides free public access to all articles. Two issues, namely scientific review on variables and dimensions of national innovation capability, as well as research findings on development and adoption of science, technology, and innovation policy and management from Japan and Indonesia, are presented.

The first article "Internal Innovation Capacity and External Lingkages in Firms of ASEAN Economies Focusing on Endogeneity" is composed by Masaru OGAWA et al. This research article examines the role of internal innovation capacity, which includes technological level, organizational learning, and human resources on innovation. The second research article entitled "Drivers of Innovation without Formal R\&D: Selected Cases of Indonesian Firms". This article is presented by Erman AMINULLAH et al. The objective of this research study is to obtain a deep understanding about "why and how" firms engaging in innovation without formal $\mathrm{R} \& \mathrm{D}$, through deep analysis of three cases of firms in machinery and food processing sectors.

Uruqul Nadhif DZAKIY presents an article entitled "Technology-based Start-up: A Formula to become Sustainable Company in Indonesia, Lessons-learned from UAVINDO Nusantara". UAVINDO is a sample of technology-based company in Indonesia which has the characteristics of sustainable company. The fourth article entitled "Development Strategy of National Microsatellite Industry: Case Study of Indonesia", is presented by Chusnul Tri JUDIANTO et al. By applying SWOT and Quantitative Strategic Planning Matrix (QSPM) methods, this research identifies and analyzes the alternative strategy from external and internal factors and selects the appropriate and precise strategy for developing the microsatellite industry.

Hadi KARDOYO et al. present an article entitled "Knowledge Accumulation-based Entrepreneurship in the Creative Industry: A Case Study of Woodwork Firms in Indonesia." This article describes the activities of knowledge-entrepreneurship in four wood craft firms, namely Radio Magno, Stranough Guitar Technologi, Secco Guitar, and Matoa Watch, and also shows some lessons from Knowledge Intensive Entrepreneur (KIE). The last article composed by Ahmad Dading GUNADI et al. presents a "Scientifc Review on National Capability Variables and Dimensions." This paper analyses the dimensions and variables of National Innovation Capability through a system approach that includes three sub-systems, namely Input, Process, and Output. 
After indexing by Google Scholar, ISJD and IPI, STIPM Journal is now indexed with DOAJ, BASE, and OCLC World Cat. This has made the journal's dissemination broader. We would like to express our immense gratitude to our international editorial board members, reviewers and authors for their contribution to this issue. We hope this publication will prove useful for readers and could contribute to the enhancement of science, technology and innovation innitiatives. We expect that STIPM will always provide a higher scientific platform for authors and readers, with a comprehensive overview of the most recent STI Policy and Management research and development at the national, regional dan international levels. Finally, wishing you a HAPPY NEW YEAR 2019. May your New Year be filled with great achievements, good health, peace, happines, and joy.

Jakarta, December 2018

Editor-In-Chief 



\section{JOURNAL OF STI POLICY AND MANAGEMENT}

Volume 3, Number 2, December 2018

\section{LIST OF CONTENTS}

Internal Innovation Capacity and External Linkages in FIRMS of ASEAN Economies Focusing on Endogeneity

Masaru Ogawa, Yasuhi Ueki, Hiroki Idota, Teruyuki Bunno, and Masatsugu Tsuji

Drivers of Innovation Without Formal R\&D: Selected cases of Indonesian firms

Erman Aminullah, Trina Fizzanty, Qinan M.B. Soesanto.

Technology-Based Startup: A Formula to Become Sustainable Company in Indonesia a Case Study from UAVINDO Nusantara

Uruqul Nadhif Dzakiy

Development Strategy of National Microsatellite Industry: Case Study of Indonesia

Chusnul Tri Judianto, Harianto, and Agus Maulana

Knowledge Accumulation-Based Entrepreneurship (KABE) in the Creative Industry: A Case Study of Woodwork Firms in Indonesia

Hadi Kardoyo, Setiowiji Handoyo, and Anugerah Yuka Asmara $161-173$

National Innovation Capability Variables and Dimensions

Ahmad Dading Gunadi, Yandra Arkeman, Rizal Syarief Siaiful Nazli, Teguh Rahardjo, and Aulijati Wachjudiningsih. 


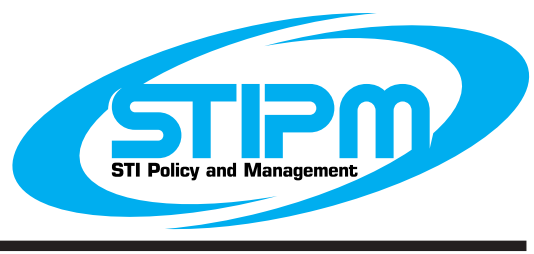

\title{
SCIENTIFIC REVIEW
}

\section{National Innovation Capability Variables and Dimensions}

\author{
Ahmad Dading Gunadi', Yandra Arkeman², Rizal Syarief Siaiful Nazli², Teguh Rahardjo ${ }^{3}$, and \\ Aulijati Wachjudiningsih ${ }^{4}$
}

${ }^{1}$ Ministry of National Development Planning, Jakarta

${ }^{2}$ Bogor Agricultural University, Bogor

${ }^{3}$ DIPI, Jakarta

${ }^{4}$ PT Geodipa Energi

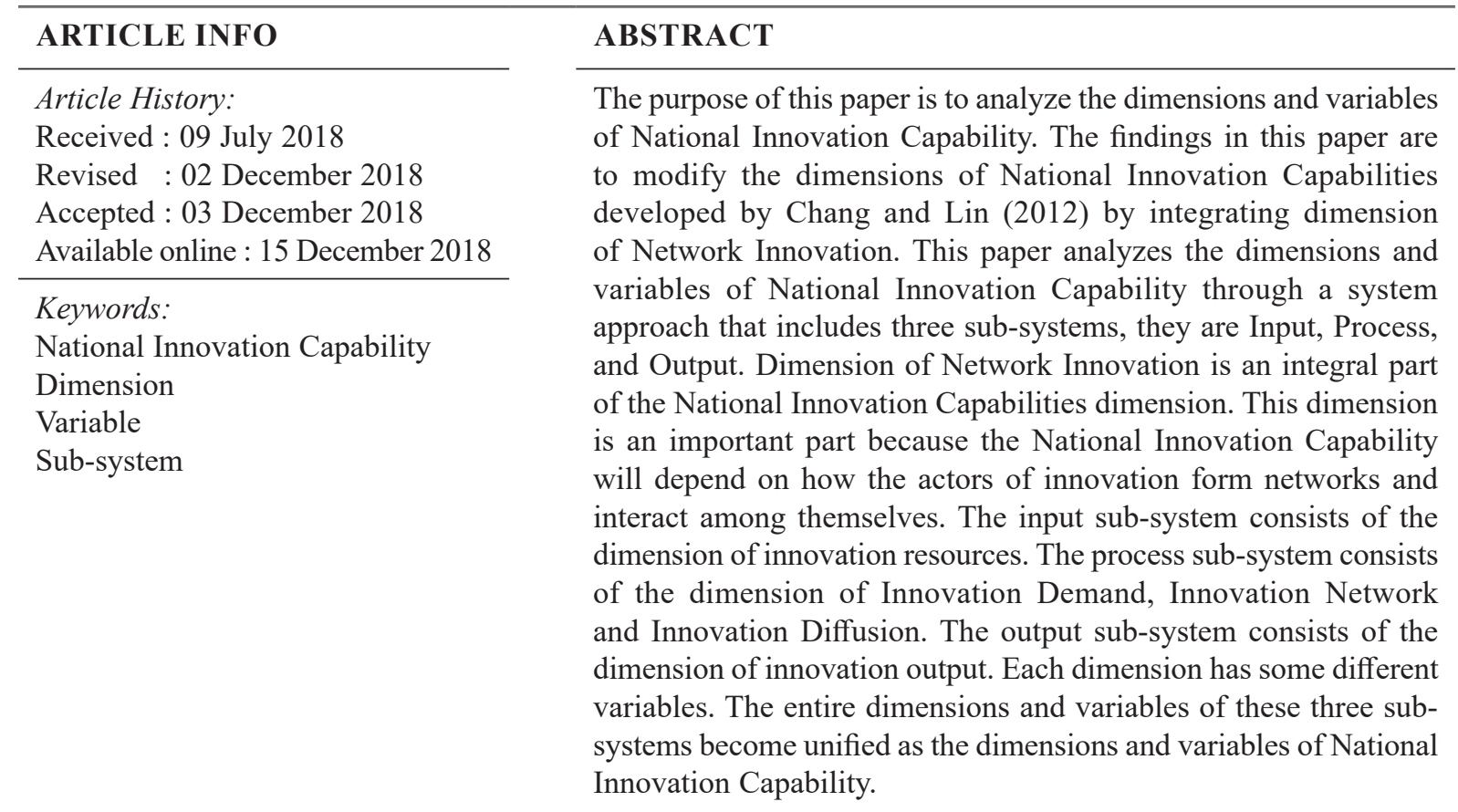

C2018 PAPPIPTEK-LIPI All rights reserved

\section{INTRODUCTION}

According to Zheng (2006), nowadays, international competition is increasing so that national innovation capability of a country becomes the key of a core competition and sustainable development capability. The capability of innovation

\footnotetext{
* Corresponding Author.

E-mail: dading@bappenas.go.id
}

plays an important role and determines who can develop rapidly in this era of globalization. For companies, innovation has the power to build competitive advantage in relation to the globalization process. For a country, innovation capabilities are a source of prosperity and economic growth (Belitz, Clemens, Schmidt-Ehmcke, \& Werwatz, 2008). 
The capability of national innovation can be broadly defined as a country's potential ability to sustain innovation activities through the implementation of a national innovation system. The criteria applied to measure national innovation abilities vary according to the level of analysis in each national conditions. Experts believe that national innovation capabilities can be measured through various aspects such as human resources, knowledge creation, knowledge dissemination and innovative financing (Commission of the European Communities, 2003). Watanabe, Akaike, and Shin (2010) proposed the idea of combining the system's point of view with various mechanisms and grouping innovation processes into 3 sub-systems, namely innovation resource input, innovation production process, and innovation market output.

In the Global Competitiveness Report (GCR) 2017-2018 issued by the World Economic Forum (WEF), the level of national competitiveness is measured by three sub-indices, namely basic requirements, improved efficiency, and innovation and sophistication factors. The three sub-indices consist of 12 pillars, namely 1) institutions; 2) infrastructure; 3) the macro-economic environment; 4) basic health and education; 5) higher education and training; 6) efficiency of the goods market; 7) efficiency of the labor market; 8) development of financial markets; 9) technology readiness; 10) market size; 11) business sophistication; and 12) innovation. Stages of building national competitiveness according to GCR are divided into three stages 1) factor driven, in which companies in a country compete based on base price and sell staple products or commodities; 2) efficiency driven, in which firms must begin to develop more efficient production processes and improve product quality; 3 ) innovation driven, in which companies must compete by producing new and different goods using sophisticated production processes. In 2017-2018, Indonesia's competitiveness status has risen, from 41 to 38 in 2016-2017. With this position, Indonesia is at the efficiency driven stage and going to the innovation driven stage.

On the $12^{\text {th }}$ pillar, i.e innovation, there are seven variables used as a measure, namely 1) innovation capacity; 2) quality of scientific research institution; 3) company research and development (R\&D) expenditure; 4) collaborative R\&D of higher education-industry; 5) government procurement of high-tech products; 6) availability of scientists and engineers; and 7) patent cooperation treaty (PCT) application/ million population. In the year 2017-2018, Indonesia's ranking of innovation pillar is 31 from 151 countries, remained at the same rank compared to 2016-2017. In detail, the data of the last five years can be seen in Table 3. The three lowest ranking variables, which contribute to the level of innovation, that still need to be improved are PCT application patents/million population, quality scientific research institutions and the availability of scientists and engineers.

Furthermore, in the Global Innovation Index (GII) issued by the Institut Européen d'Administration des Affaires (INSEAD), there are seven variables used as a measure of innovation index, which are divided into two groups: inputs and outputs. In the input group there are five variables, namely 1) institution; 2) research and human resources; 3) infrastructure; 4) markets; and 5) business. Meanwhile, in the output group there are two variables: 1) knowledge and technology; and 2) creativity. The ranking of Indonesia has decreased from $87^{\text {th }}$ in 2014 to $97^{\text {th }}$ rank in 2015 .

Indonesia needs to increase the rank of their competitiveness and innovation index because Indonesia will move to the stage of innovation driven. One of the efforts is through enhancing national innovation capability.

Relating to the national innovation capability, Chang and Lin (2012) have developed dimension of national innovation capabilities model in four dimensions, they are innovation source, innovation demand, innovation diffusion, and innovation output. These four dimensions can already describe the stages of the system approach, namely the input subsystem, process subsystem and output subsystem approaches. The input subsystem is innovation source. The innovation demand and innovation diffusion are the process subsystems. Meanwhile, innovation output is the output subsystem. 
However, this model does not involve dimensions that describe the interaction between innovation actors. This interaction is very important in the system approach and innovation process.

Therefore, this paper will modify the model developed by Chang and Lin (2012) to be more holistic and integrated. This model should be a basic reference in enhancing national innovation capabilities. The main source that will be used to modify the model is some literatures related to the national innovation capabilities.

\section{LITERATURE REVIEW}

Chang and Lin (2012) analyzed that national innovation capabilities include four dimensions, which are innovation source, innovation demand, innovation diffusion, and innovation output. The author uses empirical analysis of secondary data World Development Indicator (WDI), Global Development Finance (GDF), International Institute for Management Development (IMD), World Economic Forum (WEF), World Intellectual Property Organization (WIPO), United Nations Educational, Scientific and Cultural Organization (UNESCO) period 1991-2010 in 46 countries.

The results show that 1) there is a marked relevance between the resource of innovation (public and private R\&D ratio) to Gross Domestic Product (GDP), innovation demand (ratio of bank credit to GDP) to output innovations (patents and journals); and 2) there is no real relationship between the diffusion innovation and the output innovation.

Research conducted by Chang and Lin (2012) has a limitation that the results of research may be different depending on time and environment. They suggest advanced research, data collecting and data analysis through other longitudinal research methods. In addition, the diffusion of innovation does not directly affect the output of innovation. The popularity and application of information and communication technology is not only an indicator to measure the diffusion of innovation, but the absorption and transformation of knowledge is an important indicator of the diffusion of innovation.

To perform the analysis and modification of the model of national innovation capabilities that have been developed by Chang and Lin (2012) is by comparing studies that have been done related to the national innovation capability, such as studies done by Natario, Couto, Tiago, and Braga, (2011); Chen, Hu, and Yang, (2011); Sun (2009); Turen, Dilek, and Gokmen, (2013); Wong, Everett, \& Nicholson, (2008); Chang and Cui (2013); Stern, Porter, \& Furman, (2000); and Kutlaca (2008).

Kutlaca (2008) developed a model of national innovation capability of Serbian state taking into account the national statistical data and measurement methodology used by OECD. The concept of national innovation capability of OECD consists of four dimensions, namely the R\&D provision, absorption, diffusion, and demand. These dimensions are almost the same as those developed by Chang and Lin (2102).

Several studies analyze variables that affect national innovation capabilities, including $\mathrm{Na}$ tario, et al. (2011), Chen et al. (2011), Sun (2009), Wong, Everett and Nicholson (2008), Chang and Cui (2013), Stern et al. (2000), and Castellaci and Natera (2013).

Natario et al. (2011) conducted a study by evaluating factors affecting national innovation capability, including analysis of small and medium enterprise (SME) innovation capability using cluster analysis method. From the results of this evaluation, it was found that efficient institutional, national cultural dimension, infrastructure training and financial resources, system interaction and entrepreneurship, respectively positively influence the innovation capability. This research presents some limitations of understanding of micro mechanisms in making innovations. More detailed analysis of the effectiveness of several national innovation strategies is needed.

This research can also be developed by increasing the number of samples and considering other countries, such as the United States and Japan, given their history of innovation capabilities. In addition, further research could be done by including micro level variables to measure the real leverage of firms in countries with stronger innovation capabilities.

Meanwhile, Chen et al. (2011) examines how the innovation environment, in particular the 
national innovation system, influences the outputoriented $R \& D$ efficiency index by using linear programming technique method in order to access the decision-making unit efficiency (DMU). The results obtained are 1) almost all countries have a common R\&D efficiency in terms of patents and royalties and license fees (RLF); 2) transitional countries such as Argentina, Romania and Russia have greater efficiency in journal publications than on patent applications and technology licensing; and 3) the interaction between private $R \& D$ and college $R \& D$ has a positive relevance to the $R \& D$ efficiency index.

Sun (2009) analyzed the influence of national culture on national innovation capability with benchmarking methodology of innovation culture index. The results obtained are innovation culture variables that include individual nature, power distance, and avoidance of uncertainty related to national innovation capability.

Similarly, studies conducted by Wong et al. (2008) related to the influence of culture on innovation capabilities. In the review conducted, it was obvious that the national cultural relations with innovation were based on three perspectives: divergent, convergent, and crossvergence. The methodology used is a literature study of past research on culture, as well as culture and innovation. The result is that the crossvergence product (Chinese American culture) has a higher innovation potential than the interaction between Chinese culture. In general, Western culture tends to be more innovative than Asian cultures.

The relationship between technology transfer and diffusion (international trade, Foreign Direct Investment or FDI), R\&D institutions with national innovation capabilities was tested by Chang and Cui (2013). The result obtained from the research was that there were a long-term relationship between transfer and diffusion of transnational technologies with national innovation capabilities. In addition, there was a causal relationship between transfer and diffusion of transnational technologies with national innovation capabilities.

Stern et al. (2000) analyzed the determinants of R\&D productivity at the national level, specifically testing the relationship between international patents in the USA and the variables associated with the national innovation capability framework. This study was conducted based on data from 17 countries of Organization for Economic Co-operation and Development (OECD) in the period 1973-1996. The results of the research showed that international patent productivity is characterized by $R \& D$ financing factors, $R \& D$ workforce, Intellectual Property Right (IPR) protection policy, international trade openness, and research by private-funded universities.

Meanwhile, there are studies showing that the dynamics of national innovation systems are driven by the co-evolution of three variables of innovation capability (input innovation, scientific output, and technology output), and three factors of absorption capability (infrastructure, international trade, and human resources). This study was conducted with empirical analysis through the application of a set of indicators to measure national innovation capability in 89 countries during the period 1980-2007 (Castellacci \& Natera, 2013).

In addition, there were studies that analyzed the national innovation capabilities as an integration of regional innovation capabilities. These studies were conducted by Qing-dong and Jing (2010). They analyzed national innovation capability through the calculation of integration of innovation capability of each region in China. The methodology used was the analysis of principal components (PCA) in 15 provinces. The results of his research enables the calculation of the total capability of innovation area. In addition, it can determine a number of areas that have the best innovation capability, for example there are five best areas in terms of innovation development components, namely Beijing, Shanghai, Tianjin, Zhejiang, Jiangsu. In addition, it revealed the difference in economic growth between the central and western parts of eastern China in 2008.

Furthermore, Manzini (2012), stated that the national innovation system consists of network interaction policies, institutions and organizations that function holistically, and depends on the quality of cooperation between innovators. The synergy of innovation actors that interacts with each other will bring technological learning. Whereas learning technology facilitates the 
improvement of national innovation capability to innovate.

Innovation Union Scoringboard (2014) distinguishes three main types of indicators; they are enablers, firm activities and outputs. Then they are divided into 8 dimensions of innovation and 25 indicators. Two of the indicators is SME collaboration, and joint public-private publications. Meanwhile, the dimensions of the national innovation system developed by the Australian Innovation Scorecard consist of the creation of knowledge, human resources, finance, knowledge diffusion, college and industry cooperation, and market output.

According to Qiquan, Changlin, Welguo, and Chen (2006), the national innovation capability index includes innovation input, knowledge creation, diffusion and application of knowledge, and innovation output performance. The innovations used in European Indicator measurements consist of four groups: human resources, knowledge creation, diffusion and application of knowledge, financial innovation, output and markets. Meanwhile, innovation performance indicators used by Australia include human resources, knowledge creation, financial support, knowledge diffusion, international cooperation, and market benefits. Canada also uses innovation performance indicators that include human resources, knowledge creation, financial innovation, economic performance, and international cooperation. In summary, innovation performance indicators in Europe, Australia and Canada can be seen in Table 1.

The global innovation index includes two sub-index dimensions, namely innovation input sub-index and innovation ouput sub-index, each dependent on the pillar. The five pillars that in- clude the innovation input sub-index related to the national economy are 1) institutions, 2) research and human capital, 3) infrastructure, 4) market perfection, and 5) business perfection. These five pillars are very important as environmental prerequisites for national innovation capability. Meanwhile, there are two pillars as the innovation output sub-index: 1) the output of technology and knowledge; and 2) creative output. These two pillars show evidence of national innovation output (INSEAD, 2017).

Comparison of models of national innovation capabilities developed by Chang and Lin (2012) with other studies can be seen in Table 2. The table dimensions of innovation capabilities are grouped into five dimensions, they are innovation resources, innovation demand, innovation networks, innovation diffusion and innovation output. Nevertheless, some studies which have been done are still partial. The studies analyzed more of the relationship among the dimensions or variables of national innovation capabilities. Only the study done by Chang and Lin (2012) which had combined the 4 dimensions in their analysis, namely the innovation resource, innovation demand, innovation diffusion, and innovation output. Innovation networks are not included in this model.

Innovation network is very important to be part of dimensions of innovation capability because in innovation, interaction will occur between innovation actors. The intensity of interaction among innovation actors in the national innovation system will enhance the capability of national innovation. According to OECD (1997), innovation performance of a country depends on how much the actors are interconnected as an

Table 1.

Innovation Performance Indicators in Europe, Australia, Canada

\begin{tabular}{llllll}
\hline \multicolumn{1}{c}{ Europe } & \multicolumn{2}{c}{ Australia } & \multicolumn{1}{c}{ Canada } \\
\hline 1. & Human resources & 1. & Human resources & 1. & Human resources \\
2. & Knowledge creation & 2. & Knowledge creation & 2. & Knowledge creation \\
3. & Diffusion and knowledge & 3. & Financial support & 3. & Financial innovation \\
& application & 4. & Knowledge diffusion & 4. & Economic performance \\
4. & Financial innovation & 5. & International cooperation & 5. & International cooperation \\
5. & Output and market & 6. & Market advantage & & \\
\hline
\end{tabular}


Table 2.

Dimensions and Variables of National Innovation Capability

\begin{tabular}{|c|c|c|c|c|c|}
\hline \multirow[b]{2}{*}{ Authors } & \multicolumn{5}{|c|}{ Dimensions of National Innovation Capability } \\
\hline & Innovation Resource & $\begin{array}{l}\text { Innovation } \\
\text { Demand }\end{array}$ & $\begin{array}{l}\text { Innovation } \\
\text { Network }\end{array}$ & Innovation Diffussion & Innovation Output \\
\hline $\begin{array}{l}\text { Chang and Lin, } \\
\text { (2012) }\end{array}$ & $\begin{array}{l}\text { R\&D fund, business } \\
\text { investment, } \\
\text { education fund, } \\
\text { educated human } \\
\text { resources }\end{array}$ & $\begin{array}{l}\text { Credit funds, } \\
\text { capital markets, } \\
\text { foreign trade FDI, } \\
\text { population, GDP }\end{array}$ & & $\begin{array}{l}\text { Personal users of } \\
\text { computers and } \\
\text { internet users }\end{array}$ & Patent, journal \\
\hline $\begin{array}{l}\text { Natario, et. al. } \\
\text { (2011) }\end{array}$ & $\begin{array}{l}\text { Infrastructure, } \\
\text { culture, human } \\
\text { resources, finance, } \\
\text { institutional } \\
\text { efficiency }\end{array}$ & & $\begin{array}{l}\text { Collaboration } \\
\text { between } \\
\text { companies }\end{array}$ & & Entrepreneurship \\
\hline $\begin{array}{l}\text { Chen, et. al. } \\
(2011)\end{array}$ & $\begin{array}{l}\text { Environmental } \\
\text { innovation }\end{array}$ & & & & R\&D efficiency index \\
\hline Sun (2009) & & & $\begin{array}{l}\text { Innovation } \\
\text { culture }\end{array}$ & & Innovation capability \\
\hline $\begin{array}{l}\text { Turen, et. al. } \\
(2013)\end{array}$ & $\begin{array}{l}\text { Human } \\
\text { development level }\end{array}$ & FDI & & & $\begin{array}{l}\text { Output of science } \\
\text { and creative output }\end{array}$ \\
\hline $\begin{array}{l}\text { Wong, et. al. } \\
(2008)\end{array}$ & & & $\begin{array}{l}\text { Innovation } \\
\text { culture }\end{array}$ & & Innovation capability \\
\hline $\begin{array}{l}\text { Chang and Cui } \\
\text { (2013) }\end{array}$ & & $\begin{array}{l}\text { Technology } \\
\text { transfer }\end{array}$ & & $\begin{array}{l}\text { Diffusion of } \\
\text { technology }\end{array}$ & Patent \\
\hline $\begin{array}{l}\text { Stern, et. al. } \\
(2000)\end{array}$ & $\begin{array}{l}\text { Financing, human } \\
\text { resources, } \\
\text { protection of } \\
\text { intellectual property } \\
\text { rights (IPR) }\end{array}$ & Trade openness & & & Patent \\
\hline Kutlaca, (2008) & $\begin{array}{l}\text { Absorption } \\
\text { capability, R\&D } \\
\text { capability }\end{array}$ & $\begin{array}{l}\text { Innovation and } \\
\text { demand for R\&D }\end{array}$ & & $\begin{array}{l}\text { Absorption and } \\
\text { diffusion }\end{array}$ & \\
\hline
\end{tabular}

Table 3.

Dimensions of Innovation Capability

\begin{tabular}{ccc}
\hline $\begin{array}{c}\text { Dimensions of Innovation } \\
\text { Capability (Chang dan Lin, 2012) }\end{array}$ & Sub System & $\begin{array}{c}\text { Modification of Capability } \\
\text { Dimensions Innovation }\end{array}$ \\
\hline Innovation Resource & Input & Innovation Resource \\
\hline Innovation Demand & Process & Innovation Demand \\
\hline Innovation Diffusion & & Innovation Diffusion \\
\hline & & Innovation Network \\
\hline Innovation Output & Output & Innovation Ouput \\
\hline
\end{tabular}

element of the collective system of knowledge creation.

Therefore, it is important to combine the five dimensions into a unified whole as a complete dimension of innovation capability. These five dimensions are interrelated and could be grouped into the system, in three subsystems. The subsystems are input, process and output. Dimensions of innovation resource constitute input of the subsystem. Dimensions of innovation demand, innovation network, and innovation diffusion constitute the process of the subsystems. Meanwhile, the innovation output dimension constitute the output of the sub system. Table 3 shows the Innovation Capabilities Dimensions developed by Chang and Lin (2012) and modification of national innovation capability dimensions by 
adding the innovation network to the process sub-system.

\section{METHODOLOGY}

The methodology used in this research was literature study and interview with some key persons from government institutions, business actors, universities and research institutions. The research was conducted from Januari 2017 to February 2018.

\section{RESULTS AND DISCUSSIONS}

As outlined in Table 3, the results of the modification of the innovation capability dimension consist of five dimensions, namely innovation resource, innovation demand, innovation diffusion, innovation network, and innovation output. Each dimension consists of several variables based on various sources as described below.

\section{A. Innovation Resource}

The innovation resource is explained by Fan (2008). Financial investment and human resources in research and development are important input factors to build national innovation capability. One of the main focuses in reforming research and development is to integrate the business sector with the required knowledge and provide incentives for innovation activities.

For a country to be innovative, the state needs a well-functioning national innovation system. The national innovation system refers to companies, research institutions, and surrounding conditions that influence the process by which innovation grows. This system ensures that qualified individuals (educated), new knowledge, and adequate capital (financing) which are condolidated in the innovation process (Belitz, et al. 2008). According to Fagerberg and Srholec (2007), more attention should be devoted to the impact of the Government's mechanisms in the national innovation systems. Thus, the availability of stimulus and innovation policies from the government would influence the direction and momentum of national innovation.

\section{B. Innovation Demand}

The innovation demand, according to Kayal (2008), is the driving factor of innovation. This includes domestic market competition, research culture, international market changes, entrepreneurship, and venture capital. Ibata-Arens (2008) concluded that the national innovation system in America and Japan focuses on market demand mechanism. The study of national innovation systems should emphasize the role of markets and consumers. Thus, entrepreneurs become the subject of market information sources for new technological demand or production demand before starting the process of technological innovation.

Offer-side innovation policies have traditionally played a key role in driving innovation efforts and continuing to do so. Such policies are generally aimed at addressing market failures that characterized the innovation process and led to a lack of investment in research and innovation (Edler, Cunningham, Gok, and Shapira, 2013). They include public funds to support community, business research, development, venture capital funding, creation, infrastructure, and relationships strengthening between research and development in science and industry, and also investment in human resources (UNCTAD, 2014).

FDI has traditionally been used to exploit comparative advantage and overcome market imperfections. FDI has been increasingly used to tap into foreign innovation abilities during the innovation stages driven by global competition (Peng \& Wang, 2000).

According to Radosevic (2004), the indicators used to measure demand aspects of national innovation capability are national welfare indicators that include finance, competitiveness, and economic stability. Market capacity is the market capacity that benefits innovation including financial markets and innovation of a country.

\section{Innovation Diffusion}

The innovation diffusion is defined as the process by which innovation is communicated through channels continuously among members of the social system (Rogers, 2003). Open innovation 
is becoming increasingly important for researchers and practitioners. Open innovation is closely linked to the creation of knowledge. With open innovation, the inrush and outflow of knowledge is exploited for innovation. In the field of information systems, open innovation is closely related to software development (Eseryel, 2014).

According to Herstad, Bloch, Ebersberger, and Velde (2008), some of the indicators used to measure open innovation among others, include the magnitude of cooperation with suppliers, universities, customers, competitors, information protection, patents and magnitude of external innovation. Open innovation is mainly controlled from the establishment of knowledge networks. Therefore, information and communication technology (ICT) and knowledge flow will increase the drive to innovate and play an important role in national innovation systems.

\section{Innovation Network}

According to Bloch, Ebersberger, and Herstad (2012), several indicators used to measure open innovation include the amount of cooperation with suppliers, universities, customers, competitors, information protection, patents and the magnitude of external innovation. Open innovation is mainly controlled from the establishment of knowledge networks. Therefore, information and communication technology (ICT) and knowledge flow will increase the drive to innovate and play an important role in national innovation systems.

Innovation network is an important dimension in enhancing the capabiltias of national innovation. According to Zheng (2006), international competition is increasing all over the world, so that the national innovation capability of a country or region becomes the key to the core competition of national innovation capability improvement and national innovation system development then it becomes the focus of attention. The national innovation system refers to a nation's innovation network where there is an interaction between institutions to enhance innovation that includes economic, scientific and technological organizations.

According to Sawang and Matthews (2010), companies looking for ideas or solutions from external networks such as suppliers, or business partners show a higher level of introduction of new products compared to companies that do not have external collaboration. Collaboration between public actors and private actors creates better and more effective services and products. Collaboration enhances the role of actors in the exchange and sharing of knowledge, experience, and expertise. This brings more talent and talent, and a more responsive work culture into public organizations. Meanwhile, for the private sector it will increase the effectiveness, as it brings new financial resources, new capital, and helps facilitate innovation in an increasingly competitive environment (Cancar \& Petkovesek, 2013).

Domestic collaborations have a positive and significant influence on product innovation of micro, medium and large enterprises. Meanwhile, being a foreign subsidiary, it gives a positive and significant influence only to medium-sized companies. This is surprising given the fact that Chinese companies often seek foreign involvement to improve technology and products (Liu, Xiao, \& Huang 2008; Lu \& Beamish, 2001).

According to Belitz et al. (2008), key players in innovation, especially companies, are responsive to the encouragement of partners (network), competitors, and market demand to produce new products, services, and organizational solutions (implementation).

The social climate of innovation is found within a country as another factor of all factors. There are hidden risks in the effort to develop new technologies and products. In order to be innovative, people must have the courage to change, trust each other between innovative actors, and have a positive basis (Belitz et al. 2008). According to Fukuyama (1995), social capital has a real effect on the economic creativity of the industry. If community members work together as an entity and trust each other, based on ethical norms, then operational costs become efficient. Such a society will be better able to innovate because of the high level of trust among its members.

\section{E. Innovation Output}

International patents are best used to measure output innovation because international patents 
provide a consistent measure that can be matched by innovation measures in different countries. There are three factors why the size of the output innovation uses an international patent. First, patents on countries are very likely to reflect actual changes in inventive output, especially in measuring innovation in the developed world. Second, the international patent is not a perfect size, but the other size is very different from the concept side and the limitations of the data. Third, the international patent as a measure of output innovation is related to the commercialization process (Gans and Stern, 2003). Innovation includes technological and non-technological innovations. This indicates that the national innovative output measures are multidimensional, such as patents, royalties and licensing fees of RLF, journal articles, and so on. Meanwhile patents are widely recognized as a proxy for innovative output (Griliches, 1990).

National innovation capability refers to the output of national innovation systems, including patent output, scientific publications and hightech product exports (Taylor, 2009). The output of high-tech products demonstrated the value of innovation of a country. In other words, the increase in exports of high-tech products in GDP is a prove of an increase in technical capacity of a country (Yamashita, 1991).

Strengthening patent protection increases economic growth, but exacerbates income inequality. Therefore, when policy makers use patent policies as policy instruments to improve
$\mathrm{R} \& \mathrm{D}$ and economic growth, they need to take into account the distribution consequences that may have a negative impact on society (Chu, 2010).

According to Gould and Gruben (1996), IPR protection stimulates economic growth if accompanied by trade liberalization policies. The authors have demonstrated the positive and significant effects of IPR protection on economic growth for all developed and developing countries. More specifically speaking, the authors point out that the effects of IPR protection are more important for an open economy. By encouraging initiatives to innovate, IPR protection can affect the growth of an open country. Furthermore, Park and Ginarte (1997) show that IPR affects indirect economic growth by stimulating the accumulation of production factors such as physical capital and R\&D capital.

\section{F. Dimensions and Variables of National Innovation Capability}

In a system, there are three subsystems, namely input, process, and output. The dimensions of national innovation capability can be grouped into three subsystems. In Input subsystem there is dimension of innovation resource. In process subsystem, there are three dimensions of innovation, namely innovation demand, innovation network, and innovation diffusion. In output subsystem there is an output innovation. The relation between the three subsystems can be seen in Figure 1.

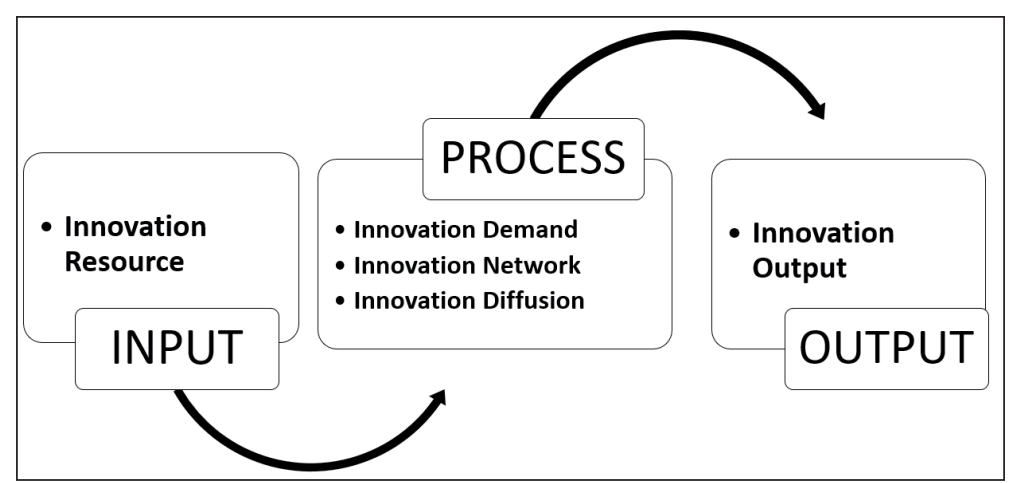

Source: Chang \& Lin (2012), Natario et. al. (2011), and OECD (1997)

Figure 1. Subsystem of National Innovation Capability Dimension 
Table 4.

Dimensions and Variables of National Innovation Capability

\begin{tabular}{|c|c|}
\hline \multicolumn{2}{|c|}{ OUTPUT } \\
\hline \multicolumn{2}{|c|}{ Innovation Output } \\
\hline 1. & Number of Patent \\
\hline 2. & Number of Scientific Publication \\
\hline 3. & Value of High Technology Products Exports \\
\hline \multicolumn{2}{|c|}{ PROCESS } \\
\hline \multicolumn{2}{|c|}{ Innovation Demand } \\
\hline 1. & Foreign Trade Value \\
\hline 2. & Value of Foreign Direct Investment (FDI) \\
\hline 3. & Population \\
\hline 4. & GDP \\
\hline \multicolumn{2}{|c|}{ Innovation Network } \\
\hline 1. & The number of Collaborative R\&D Research with industry \\
\hline & The Social and Cultural Level of Innovation \\
\hline 3. & International Research Cooperation \\
\hline \multicolumn{2}{|c|}{ Innovation Diffusion } \\
\hline 1. & Number of Intermediation/Incubation Institutions \\
\hline 2. & Number of Science Techno Parks (STP) \\
\hline \multicolumn{2}{|c|}{ INPUT } \\
\hline \multicolumn{2}{|c|}{ Innovation Resource } \\
\hline 1. & Amount of Government Research Funding \\
\hline 2. & Amount of Private Research Funding \\
\hline 3. & Amount of Education Budget \\
\hline 4. & Number of Human Resources/Researchers \\
\hline 5. & Number of Lecturers \\
\hline
\end{tabular}

The dimensions of innovation resource consists of a number of variables: amount of funding of government and private research, amount of education budget, number of researchers, and number of lecturers. Dimensions of innovation diffusion consist of variables: number of intermediation/incubation institutions, and number of science techno parks (STP). In the dimensions of the innovation network, the variables used as indicators are the number of collaborative $R \& D$ research with industry, social and cultural level of innovation, and international research cooperation. Dimensions of innovation demands consist of foreign trade value, FDI value, population size, and GDP value. Meanwhile, in the dimensions of Output Innovation, there are three variables, namely number of patents, number of scientific publications, export value of high-tech products. More clearly are described in Table 4.

In the modified model shown in Figure 1, additional dimensions of innovation network is very important. Some studies explained the importance of innovation network dimensions are Suh and Kim (2012), Sawang and Matthews (2010), Zheng (2006), Jung and Andrew (2014), and Adams, Chiang, and Starkey (2001).

Innovation networks provide a greater impact in the product development process of the transfer of technology or product development in industrial research. According to Suh and Kim (2012), R\&D networks are positively related to product or service innovation, patent activities, and process innovation. Furthermore, according to Sawang and Matthews (2010), the network can enhance the role of the actors in the exchange and sharing of knowledge, experience, and expertise. The network between public actors and industry actors will create better and more effective services and products. According to Zheng (2006), the national innovation system refers to the innovation network of a country where there is interaction between institutions to increase innovation which includes economic, scientific and technological organizations. 
R\&D networks can reduce costs, increase profitability, and produce spillover benefits (Jung \& Andrew, 2014). According to Adams et al. (2001), the direct transfer of technology from universities and R\&D institutions to companies is facilitated by their networks in R\&D activities. By transforming technology into products, companies can maintain a symbiotic relationship with universities and R\&D institutions. Rene, Martin, Boris, and Juan (2015) found that continuous networks have a systematic positive effect on innovation. Furthermore Czarnitzki, Ebersberger, and Fier (2007) stated that networking has a positive effect. In Germany, subsidies for individual research do not show a significant impact on R\&D or on patents, but innovative performance can be enhanced with additional incentives for networking.

In addition, one of the measures in the pillar of innovation in the competitiveness index is the collaboration of R\&D between higher education and industry. Collaboration is part of network that characterized their cooperation with other parties. Thus, the innovation capability model that has been developed by Chang and Lin (2012) really needs to be modified with additional dimensions of the innovation network. This will illustrate the occurrence of a very interactive process among innovators.

\section{CONCLUSION}

Chang and Lin (2012) have developed model of national innovation capabilities that include four dimensions that are innovation source, innovation demand, innovation diffusion, and innovation output. This model needs to be modified in order to accommodate the variable showing interactions among actors of innovation. Related to the national innovation capability, some studies have been done.

These studies can be grouped into 3 categories: 1) studies that analyze factors influencing national innovation capability; 2) studies that analyze the capabilities of national innovation as an integration of regional innovation capabilities; and 3) studies of structural modeling of innovation capability by looking at input, process and output factors.
Group studies 1 and 2 analyzed correlations between dimensions, but they have not analyzed the integrated dimensional model of innovation capability. Meanwhile, group studies 3 analyzed the integrated dimensional capabilities of inputs, processes and outputs.

Based on these earlier studies, there is a dimension of innovation networks that has not been integrated into group studies 3 . Therefore, it is necessary to incorporate the innovation network as one of the dimensions into the model of national innovation capability that has been developed by Chang and Lin (2012).

Completely, the dimensions of national innovation capability are divided into three subsystems, namely input, process, and ouput. In input subsystem there is a dimension of innovation resource. In the process of subsystem there are innovation demand dimension, innovation network dimension, and innovation diffusion dimension. In the output subsystem there is innovation output dimension.

The dimensions and variables of national innovation capability could be used to analyze which factors are most influential in enhancing national innovation capabilities. Thus, the Government can determine the priority dimensions and variables that could become the main driving factors in improving national innovation capability.

Dimensions and variables of national innovation capability can be used as a reference for reviewing indicators of national innovation capability index.

The changes of time and environment cause difference on dimensions and variables of national innovation capability. Thus, for advanced research, it is advisable to collect and analyze data in accordance with the development.

\section{REFERENCES}

Adams, J., Chiang, E., \& Starkey, K. (2001). Industryuniversity cooperative research centers. Journal of Technology Transfer, 26(1, 2), 73-86.

Belitz, H., Clemens, M., Schmidt-Ehmcke, \& Werwatz, J. (2008). Deficits in education endanger Germany's innovative capacity. DIW Berlin, 14(4), 86-93. 
Bloch, C., Ebersberger, B., \& Herstad, S. J. (2012). Open innovation practices and their effect on innovation performance. International Journal of Innovation and Technology Management, 9(6), 1-22.

Cancar, S. S., \& Petkovesek, V. (2013). Private and public sector innovation and the importance of cross-sector collaboration. Journal of Applied Business Research, 29(6), 1.597-1.606.

Castellacci, F., \& Natera, J. M. (2013). The dynamics of national innovation systems: A panel cointegration analysis of the coevolution between innovative capability and absorptive capacity. Research Policy 42 (3), 579-594.

Chang, S. C., \& Lin, P. H. (2012). A preliminary study on the structural model of national innovation capability. The Journal of International Management Studies, 7(1), 128-137.

Chang, Y., \& Cui, X. (2013). The interactive relationship of transnational technology transfer \& diffusion and national innovation capability. International Journal of Business and Management, 8(21), 76-88.

Chen, P. C., Hu, J. L., \& Yang, C. H. (2011). An international comparison of R\&D efficiency of multiple innovative output: The role of the national innovation system. Innovation: Management, policy \& practice, 13, 341-360.

Chu, A. C. (2010). Effects of patent policy on income and consumption inequality in a R\&D Growth Model. Southern Economic Journal, 77(2), 336-350.

Commission of the European Communities (2003). European Innovation Scoreboard: Technical Paper No. 1 Indicators and Definitions. Luxembourg: Commission of the European Communities.

Czarnitzki, D. Ebersberger, B., \& Fier, A. (2007). The relationship between $\mathrm{R} \& \mathrm{D}$ collaboration, subsidies and R\&D performance: Empirical evidence from Finland and Germany. Journal of Applied Econometric, 22( 7), 1346-1366.

Edler, J., Cunningham, P., Gök, A., \& Shapira P. (2013). Impacts of innovation policy: Synthesis and conclusion. (Compendium of evidence on the effectiveness of innovation policy No. 20). Manchester: University of Manchester, Business School-National Endowment for Science, Technology and the Arts.

Eseryel, U. Y. (2014). IT-enabled knowledge creation for open innovation. Journal of the Association for Information Systems, 15(Special Issue), 805-834.
Fagerberg, J. \& Srholec, M. (2007). National innovation system, capabilities and economic development. (TIK Working Paper on Innovation Studies 20071024). Oslo: university of Oslo.

Fan, P. (2008). Innovation capacity and economic development: China and India. (Research Paper, UNU-WIDER, United Nations University (UNU), No. 2008/31). Tokyo: UN University.

Fukuyama, F. (1995). Trust: The social virtues and the creation of prosperity. New York: The Free Press.

Gans, J. \& Stern, S. (2003). Acessing Australia's innovative capacity in the $21^{\text {st }}$ Century. Melbourne: Law School Building.

Global Economic Forum. (2017). The global competitiveness report 2017-2018. Retrieved 25 December 2017 from https://www.weforum. org/reports/the-global-competitivenessreport-2017-2018 .

Gould, D. M., \& Gruben, W. C. (1996). The role of intellectual property rights in economic growth. Journal of Development Economics, 48(2), 323-350. http://dx.doi.org/10.1016/03043878(95)00039-9

Griliches, Z. (1990). Patent statistics as economic indicators: A survey. Journal of Economic Literature, 28(4), 1661-1707.

Herstad, S. J., Bloch, C., Ebersberger, B. \& Velde, E. (2008). Open innovation and globalisation: Theory, evidence and implications. (NIFU STEP Report 4/2008). Oslo: NIFU.

Ibata-Arens, K. (2008). Comparing national innovation systems in Japan and the United States: Push, pull, drag and jump factors in the development of new technology. Asia Pacific Business Review, 14(3), 315-338.

European Commission. (2014). Innovation union scoreboard 2014: The innovation union's performance scoreboard for research and innovation. Annex H: Performance indicator. Brussel: Directorate General for Enterprise and Industry, European Commission. Retrieved from http:// ec.europa.eu/DocsRoom/documents/6993/ attachments/1/translations/en/renditions/native, 25 December 2017.

INSEAD (Institut Européen d'administration des Affaires). (2017). The global innovation index 2017 Report. Retrieved from https://www. globalinnovationindex.org/. Access dated December 25, 2017. 
Jung, K., \& Andrew, S. (2014). Building R\&D collaboration between university-research institute and small medium-size enterprises. International Joutnal of Social Economics. 41(12), 1174-1193.

Kayal, A. A. (2008). National innovation systems a proposed framework for developing countries. International Journal Entrepreneurship and Innovation Management, 8(1), 74-86.

Kutlaca, D. (2008). Measurement of national innovation capacity: Indicators for Serbia. Paper presented at PRIME Indicators Conference, Oslo, May 28-30, 2008.

Liu, X., Xiao, W., \& Huang, X. (2008). Bounded entrepreneurship and internationalization of indigenous Chinese private-owned firms. International Business Review, 17, 488-508.

Lu, J. W. \& Beamish, P. W. (2001). The internationalization and performance of SMEs. Strategic Management Journal, 22, 565-586.

Manzini, S. T. (2012). The national system of innovation cencept: An ontological review and critique. South Africa Journal Sci, 108(9/10). http://dx.doi.org/10.4102/sajs.v108i9/10.1038.

Natario, M. M. S., Couto J. P. A., Tiago, M. T. B., \& Braga, A. M. M. (2011). Evaluating the determinants of national capacity among European countries. Global Journal of Management and Business Research, 11(11), 67-78.

OECD. (1997). National innovation system. Paris: OECD Publication.

Park, W. G. \& Ginarte, J. C. (1997). Intellectual property rights and economic growth. Contemporary Economic Policy, 15(3), 51-61. http://dx.doi.org/10.1111/j.1465-7287.1997. tb00477.x

Peng, M. W., \& Wang, D. Y. (2000). Innovation capability and foreign direct investment: Toward a learning option perspective. Management International Review, Special Issue 2000/1, 79-93.

Qing-dong, L., \& Jing, N. (2010). Evaluation on Integrated innovation capability of regions based on principal component analysis. Canadian Social Science, 6(4), 12-19.

Qiquan, Y., Changlin, G., Welguo, S., \& Chen, W. (2006). Benchmarking national innovation capability: Indicators frameworks and primary findings. national research center for science and technology for development. Paper presented at Workshop on Indicator OECD-MOST, China.
Radosevic, S. (2004). A two tier or multitier Europe? Assesing the innovation capabilities of Central and East European Countires in the enlarged EU. Journal of Common Market Studies, 4C(3), 641-666.

Rene, B., Martin, C., Boris, L., \& Juan, F. S. (2015). Inter-temporal patterns of R\&D collaboration and Innovative performance. Journal of Technology Transfer, 40(1), 123-137.

Rogers, E. M. (2003). Diffusion of Innovations, $5^{\text {th }}$ Edition. New York: The Free Press, A Division of Simon \& Schucter, Inc.

Sawang, S., \& Matthews, J. H. (2010). Positive relationships among collaboration for innovation, past innovation abandonment and future product introduction in manufacturing SMEs. Interdisciplinary Journal of Contemporary Research in Business, 2(6), 106-117.

Stern, S., Porter, M. E., \& Furman, J. L. (2000). The determinant of national innovative capacity. (NBER Working Paper No. 7876, September). Cambridge: NBER.

Suh, Y., \& Kim, M. S. (2012). Effects of SME Collaboration on R\&D in the Service Sector in Open Innovation. Innovation, Management, Policy \& Practice, 14(3), 349-362.

Sun, H., (2009). A meta-analysis on the influence of national culture on innovation capability. Int. J. Entrepreneurship and Innovation Management, $10(3 / 4)$

Taylor, M. Z. (2009). International linkages and national innovation rates: An exploratory probe. Review of Policy Research, 26(1/2), 127-149.

Turen, U., Dilek, D., \& Gokmen. (2013). Exploring the impact of foreign direct investment accumulation on national innovation capability and the mediating role of human development level. International Journal of Social Inquiry, 6(1), 49-72.

UNCTAD. (2014). Science, technology and innovation capability gaps, policy environment, and evolving policy tools for sustainable development. Washington DC: United Nations.

Watanabe, C., Akaike, S., \& Shin, J. H. (2010). Adaptive efficiency of Japan's national innovation system toward a service oriented economy. Journal of Service Research, 10(1), AprilSeptember.

Wong, Y. Y., Everett, A. M., \& Nicholson, J. D. (2008). National culture and innovation capability: Some observations concerning Chinese-Americans. Managemen Research News, 31(9), 697-712. 
Yamashita, S. (1991). Transfer of Japanese technology and management to the ASEAN countries. Tokyo: University of Tokyo Press.
Zheng, X. P. (2006). Research review on national innovation system. Scientific Management Research, 24(4),1-5. 